\title{
THE ROLE OF DIFFUSION-WEIGHTED MRI OF PATIENTS WITH SPINE METASTASES
}

\author{
O PAPEL DA RM PONDERADA POR DIFUSÃO DE PACIENTES COM METÁSTASES DA \\ COLUNA VERTEBRAL
}

\section{EL PAPEL DE LA RM PONDERADA POR DIFUSIÓN DE PACIENTES CON METÁSTASIS DE LA COLUMNA VERTEBRAL}

\author{
Vadim Anatol'evich Brvaltsev, ${ }^{1,2,3,4}$ Ivan Andreevich Stepanov, ${ }^{1,2}$ AleXander Ivanovich Kichigin ${ }^{1}$ \\ 1. Irkutsk State Medical University, Irkutsk, Russia. \\ 2. Railway Clinical Hospital, Irkutsk, Russia. \\ 3. Irkutsk Scientific Center of Surgery and Traumatology, Irkutsk, Russia. \\ 4. Irkutsk State Medical Academy of Continuing Education, Irkutsk, Russia.
}

\begin{abstract}
Objective: The role of diffusion-weighted MRI in differential diagnostics and predicting the survival of patients with spine metastases was studied. Methods: The study included data from MRI and morphological studies of 23 patients with spine metastases. Results: The values obtained for the apparent diffusion coefficient (ADC) of tumors were compared with their histological type, cell density and Ki-67 proliferation index. The effect of ADC values on overall patient survival was also assessed. A reliable inverse correlation was established between ADC values and Ki-67 proliferation index for various types of spine metastases $(r=-0.753, p=0.017)$. The dependence of ADC values and overall survival of patients with metastases in the spine is shown. Conclusion: The technique of diffusion-weighted MRI can be used as part of a comprehensive assessment in the preoperative planning of surgical treatment, and as a prognostic factor of overall survival for this group of patients. Level of Evidence II. Prognostic retrospective study,
\end{abstract}

Keywords: Spine; Neoplasm Metastasis; Diffusion Magnetic Resonance Imaging; Cell Proliferation; Survival.

\section{RESUMO}

Objetivos: O papel da RM ponderada por difusão nos diagnósticos diferenciais e na previsão da sobrevida dos pacientes com metástases da coluna vertebral foram analisados. Métodos: O estudo incluiu dados da RM e estudos morfológicos de 23 pacientes com metástases da coluna vertebral. Resultados: Os valores obtidos para o coeficiente de difusão aparente (ADC) dos tumores foram comparados com seu tipo histológico, densidade celular e índice de proliferação Ki-67. Além disso, avaliou-se o efeito dos valores de ADC na sobrevida global dos pacientes. Foi estabelecida uma correlação inversa confiável entre os valores de ADC e o índice de proliferação Ki-67 para diversos tipos de metástases da coluna vertebral ( $r=-0,753$, $p=0,017)$. A dependência dos valores de ADC e a sobrevida global dos pacientes com metástases na coluna vertebral é demostrada. Conclusão: A técnica da RM ponderada por difusão pode ser utilizada como parte de uma avaliação abrangente do planejamento pré-operatório do tratamento cirúrgico e como fator prognóstico da sobrevida global para esse grupo de pacientes. Nível de Evidência II. Estudo retrospectivo prognóstico.

Descritores: Coluna Vertebral; Metástase Neoplásica; Imagem de Difusão por Ressonância Magnética; Proliferação de Células; Sobrevida.

\section{RESUMEN}

Objetivos: Fueron analizados el papel de la RM ponderada por difusión en los diagnósticos diferenciales y en la previsión de la sobrevida de los pacientes con metástasis de la columna vertebral. Métodos: El estudio incluyó datos de RM y estudios morfológicos de 23 pacientes con metástasis de la columna vertebral. Resultados: Los valores obtenidos para el coeficiente de difusión aparente (ADC) de los tumores se compararon con su tipo histológico, densidad celular e índice de proliferación Ki-67. Además, se evaluó el efecto de los valores de ADC en la sobrevida global de los pacientes. Se estableció una correlación inversa confiable entre los valores de ADC y el índice de proliferación Ki-67 para diversos tipos de metástasis de la columna vertebral ( $r=-0,753, p=0,017)$. Es demostrada la dependencia de los valores de ADC y la sobrevida global de los pacientes con metástasis en la columna vertebral. Conclusión: La técnica de RM ponderada por difusión puede utilizarse como parte de una evaluación integral de la planificación preoperatoria del tratamiento quirúrgico y como un factor pronóstico de la sobrevida global para este grupo de pacientes. Nivel de Evidencia II. Estudio retrospectivo pronóstico.

Descriptores: Columna Vertebral; Metástasis de Neoplásica; Imagen de Difusión por Resonancia Magnética; Proliferación Celular; Sobrevida.

\section{INTRODUCTION}

Metastases to the spine and paravertebral tissues affects $40 \%$ of cancer patients. Due to the development of methods for the treatment of cancer, the life expectancy of patients is increasing steadily. However, as the life expectancy of cancer patients increases, so too will the number of patients with spinal metastases. ${ }^{1}$
The treatment of patients with spinal metastases usually includes pain management, radiation, surgery and medical, radiation therapy and/or surgical treatment. New types of the targeted chemotherapy based on bisphosphonate or denosumab are also emerging. Treatment options may include total percutaneous thermal ablation, stereotactic spine radiosurgery, vertebroplasty and kyphoplasty. 
Nevertheless, despite its high incidence, tumors of spinal metastases continue to present a problem for modern neuro-oncology due to the lack of uniform clinical guidelines for the management of this group of patients, and the limited possibilities of chemotherapy, radiotherapy and targeted therapy. ${ }^{2}$

Careful visualization of the distribution process is required to determine a patient management strategy that includes a proper preliminary assessment of the possibility of surgical treatment, as well as the planning of radiation therapy.

Of the available diagnostic methods for diseases of the spine, $\mathrm{MRI}$ scan is the most appropriate tool in the daily practice of the physician. This method has a high resolution and is able to visualize both bone and soft tissue structures of the vertebral canal, enabling the extent of the metastasis to be accurately determined. Regardless of the histogenesis of metastatic tumors, the MR-signal does not show any significant differences in the T1 and T2-WI. ${ }^{2}$ The standard examination protocol includes native and postcontrast study. During MRI scanning for the purpose of differential diagnosis, STIR and FLAIR are commonly used sequences. Methods of diffusion-weighted $\mathrm{MRI}$ with the construction of ADC maps enables visualization of restriction of diffusion of water molecules associated with proliferative activity and high cell density, which is typical for the tumor process. The use of ADC maps enables the nature of the lesion to be differentiated. In particular, the research shows that the ADC value of vertebral hemangiomas is significantly higher than that of malignant lesions. High priority is given to MRI tractography is a method of visualizing the course of nerve fibers, based on a programmatic analysis of the orientation of diffusion ellipsoids in neighboring voxels, which allows reconstructing the pathways of the spinal cord in axial, frontal and sagittal projections, assist in the differential diagnosis of intramedullary formations and determine the nature of the neoplastic process (infiltrative or expansive growth), which plays an important role in the preoperative planning. ${ }^{3}$ Clear visualization of the metastases in the MRI can be used for high-precision radiation therapy. Researchers have reported, in particular, on the possibility of integrating a 1.5T MRI scanner with a linear accelerator. ${ }^{4,5}$ Multislice computed tomography (MSCT) enables the identification of areas of lytic destruction of the vertebrae with violation of the integrity of the cortical layer and soft-tissue component in the paravertebral soft tissues or spinal canal with bolus contrast enhancement. A bone scan is a screening technique that reveals the presence of metastases in the bones. It has the advantages of the ability to diagnose metastatic lesions in the early stages, a relatively low radial load, speed, and the ability to study the entire skeleton. Single photon emission computed tomography (SPECT) creates 3Dimages, in contrast to isotope scanning (scintigraphy), using the same principle of creating gamma photons but creating a two-dimensional projection only. Positron emission tomography (PET) is used in cases where there are difficulties in interpreting formations in the spine and spinal cord, as it allows the neoplastic nature of the disease to be determined based on its increased metabolic activity. ${ }^{6,7}$ Early diagnosis and surgical intervention can improve both the outcome and survival of patients. $^{8}$ The median survival of patients with detected metastases to the spine is less than 5.1 months. The quality of life of these patients is reduced due to progressively increasing pain. Overall survival is one of the most important criteria in modern neuro-oncology, and increasing it is one of the main goals of clinical research..$^{8-11}$

The purpose of this study was to evaluate the role of diffusionweighted magnetic resonance imaging (DW-MRI) in the differential diagnosis and prediction of survival of patients with metastatic tumors of the spine by matching received values of ADC' tumors with their histological type, cell density and Ki-67 proliferation index.

\section{METHODS}

A single-center retrospective non-randomized cohort study.

The study includes cases of single metastases to the spine confirmed by pathomorphological studies.

Exclusion criteria were cases of multiple metastatic lesions.

The study was performed in the Neurosurgical Center of the
Road Clinical Hospital at St. Irkutsk-Passenger (Irkutsk, Russia).

The study was conducted between July 2015 and August 2017.

MRI of the spine was performed on all patients in the preoperative period, in various modes. In all cases, the removal of tumors was performed by a single surgical team with the highest possible degree of radicalism, using microneurosurgical techniques and under magnification with an OPMI Pentero 900 surgical microscope (Carl Zeiss, Germany). Excised tumors were submitted to pathomorphological examination. The data from the MRI studies and pathomorphological findings were compared. The overall patient survival was estimated, from the moment the patient was enrolled in the research until death by any cause.

The values of ADC, Ki-67 indices and cell density for different histological types of metastatic tumors of the spine were defined, and the correlation between these parameters was set. The result of the study revealed that $A D C$ is a reliable predictor of survival for patients with metastases in the spine.

MRIs (T1-, T2-WI and DWI) for all patients estimated in the research were obtained using a Siemens Magnetom Essenza 1.5 T (Germany) MRI scanning device (Figures 1A, B, C, D). For the study in the sagittal plane, the following parameters were used: T2-WI - matrix $363 \times 363$, TR (time repetition) - 3500, TE (time of echo) - 100, NA (number of excitations) 1, slice thickness - 4 mm, FOV - 48×49. Data for T1-Wl: matrix $358 \times 358$, TR -400 , TE -7.8 , NA -2 , slice thickness $-4 \mathrm{~mm}$, FOV $-48 \times 49$. For the study in the axial plane, the parameters used were: T2-WI - matrix $180 \times 180$, TR (time repetition) - 3500, TE (time to echo) is 120 , NA (number of excitations) - 3 , slice thickness $-4 \mathrm{~mm}$, FOV (field of view) $-20 \times 25$. To obtain a DWI, the following set of parameters of options DW MRI with spin-echo EPI was used: matrix $384 \times 384$, TR - 591, TE - 76, NA - 1, slice thickness $-7 \mathrm{~mm}$, FOV of $20 \times 25$. B factor values of $1000 \mathrm{sec} / \mathrm{mm}^{2}$ are used. The average scanning time was 12 minutes.

ADC was calculated for several DWI with the largest diameters of the tumor. Cystic and necrotic areas of the tumors were not included in the area of interest. The calculation of ADC was performed using the program Inobitec DICOM viewer.

All excised tumors were investigated by experienced pathologists. During the morphological study of metastatic tumors of the spine, the following parameters were evaluated: the histological type of tumor, the Ki-67 proliferation index based on monoclonal antibodies MIB-1 (DakoCytomation, Denmark), and the cellular density of the tumor tissue (Figures 1D, E). Cell density was determined using the program "Image J" with total $\times 400$ magnification under an AxioLab (Carl Zeiss, Germany) microscope, using the method of M. Abercrombie. ${ }^{12}$ The density value was expressed in cells $/ \mathrm{mm}^{3}$.

The study was approved by the ethical committee of Irkutsk State Medical University (No. 7 of 10.02.2017). The study was conducted in accordance with the principles of good clinical practice and the Helsinki Declaration. Before the study, patients provided written informed consent.

The statistical data were processed using the software program Microsoft Excel 2010. All measurements are checked for accuracy by the test of Kolmogorov-Smirnov. The data were then estimated using descriptive statistics (absolute and relative values). Categorical variables are expressed as percentages. The analysis of overall survival was performed using the Cox unadjusted proportional hazards regression model to estimate the $95 \%$ confidence intervals $(95 \% \mathrm{Cl}$ ). Kaplan-Meier curves were used to estimate overall survival. The comparative analysis of ADC values, Ki-67 labeling indices and cell density was performed using the Mann-Whitney test. Spearman's coefficient was used to evaluate the correlation between ADC values of the tumors, cell density and Ki-67 labeling index. A threshold level of significance of $p=0.05$ was selected.

\section{RESULTS}

The study included MRIs with DWI of 23 patients with metastatic tumors in the spine who were operated in the in the Neurosurgical Center of the Road Clinical Hospital at St. Irkutsk-Passenger (Irkutsk, Russia) in the period July 2015 to August 2017. The patients included 

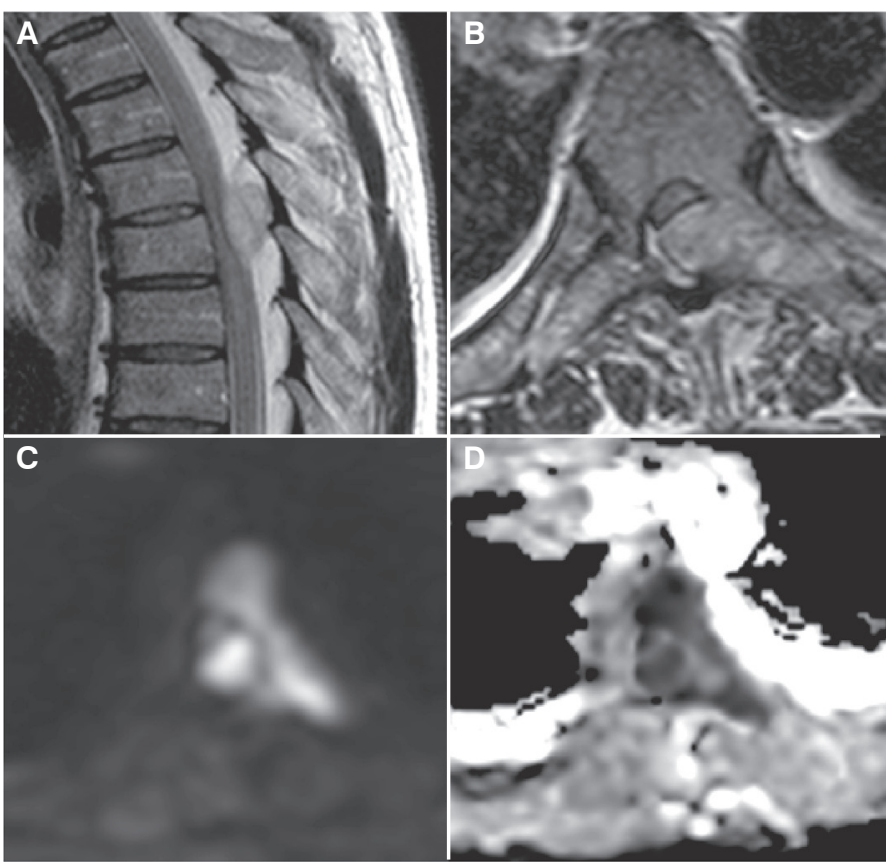

Figure 1. MRIs of lung adenocarcinoma metastasis in the body and left shank ThX vertebrae with compression of the spinal cord and nerve root on the left: A — T2 sagittal, B - T2 axial; C - DWI b-1000 mm2/s, D - ADC-map (compare ADC in the pathological process zone $=671 \mathrm{~mm} 2 / \mathrm{s}$ ).

12 women and 11 men, aged from 31 to 75 years (average age $54.9 \pm 11.6$ years). The histological tumor types are shown in Table 1.

The mean ADC values for the different types of metastatic tumors were compared, and showed significant difference $(p<0.01)$ (Figure 2). Meanwhile, the highest average ADC values were found for metastases from the kidney, colon and sarcoma of the ovary $\left(1053.5 \pm 79.3,1015 \pm 89.1\right.$ and $1035.3 \pm 68.7 \mathrm{~mm}^{2} / \mathrm{sec}$, respectively). The lowest average values of the ADC were found for metastases to the spine from prostate adenocarcinoma, breast adenocarcinoma and non-small cell lung cancer (NSCLC) $(720.2 \pm 56.7,891.5 \pm 173.4$ and $880.6 \pm 79.1 \mathrm{~mm}^{2} / \mathrm{sec}$ respectively).

The mean cell density values in metastatic brain tumors of different histologic types were as follows: metastases from malignant tumors of the breast $-972.7 \pm 73.8 \mathrm{cells} / \mathrm{mm}^{3}$, adenocarcinoma of the prostate, $1203 \pm 223.1 \mathrm{cell} s / \mathrm{mm}^{3}$, easy $-1164.5 \pm$ of $404.3 \mathrm{cell} s / \mathrm{mm}^{3}$, metastatic renal cell carcinoma $-1285.7 \pm 432.5$ cells $/ \mathrm{mm}^{3}$, adenocarcinoma of the colon $-1403 \pm 210.8 \mathrm{cell} / \mathrm{s} / \mathrm{mm}^{3}$ and metastasis from ovarian sarcoma $-954 \pm 336.8$ cells $/ \mathrm{mm}^{3}$. There were no statistically significant differences in the compared average cell density values for different types of spine metastasis $(p>0.05)$ (Figure 3 ).

The mean values for the Ki-67 proliferative activity index for various types of metastatic tumors varied widely: metastases from malignant lung tumors $-41.6 \pm 3.5 \%$, breast cancer $43.5 \pm 8.8 \%$, kidney cancer and $23 \pm 2$ cells $/ \mathrm{mm}^{3}$, adenocarcinoma of the colon

Table 1. Histological types of metastatic spine tumors.

\begin{tabular}{c|c|c}
\hline Histological type & N & Source of metastasis \\
\hline Small cell carcinoma & 1 & Lung \\
\hline Papillary adenocarcinoma & 1 & Lung \\
\hline Non-small cell carcinoma & 1 & Lung \\
\hline Tubular adenocarcinoma & 4 & Breast \\
\hline Squamous cell carcinoma & 3 & Breast \\
\hline Renal cell carcinoma & 2 & Kidney \\
\hline Clear cell adenocarcinoma & 1 & Kidney \\
\hline Mucinous adenocarcinoma & 4 & Ascending Colon \\
\hline Stromal sarcoma & 1 & Ovary \\
\hline Acinar adenocarcinoma & 5 & Prostate \\
\hline
\end{tabular}

- $24 \pm 4.2 \%$, adenocarcinoma of the prostate $39.4 \% \pm 3.5$ cells/ $\mathrm{mm}^{3}$ and ovarian sarcoma $-29.3 \pm 13.6 \%$. Comparison of the mean values of the Ki-67 proliferative index for various types of spine metastases also showed no significant differences ( $p>0.05)$ (Figure 4).

The correlation between ADC values and cellular density of the various types of metastatic spinal tumors showed no statistically significant relationships $(r=0.477, p=0.367)$. The correlation between ADC and the Ki-67 proliferation index showed a significant inverse relationship $(r=-0.756, p=0.017)$

The evaluation of the effect of ADC values on the overall patient survival showed that if the ADC value for metastatic spinal tumors was greater than $964.8 \mathrm{~mm}^{2} / \mathrm{sec}$, then the average overall survival was 10.2 months (95\% Cl: 9.5-12.4); if the ADC value was at least 964.8 $\mathrm{mm}^{2} / \mathrm{sec}$, the average overall survival was significantly lower, at 7.3 months (95\% Cl: 4.1-10.5, $\mathrm{p}=0.021$ ). The correlation between the ADC of metastatic tumors and overall survival is shown in Figure 5.

\section{DISCUSSION}

The data from different authors confirm that the ADC values correlate with cellular density and histologic type of various tumors. ${ }^{13-15}$ For metastatic tumors, there is also a connection between high cell density and low differentiation in tumors with low ADC values. ${ }^{16,17} \mathrm{~A}$ significant negative correlation between ADC values and the Ki-67

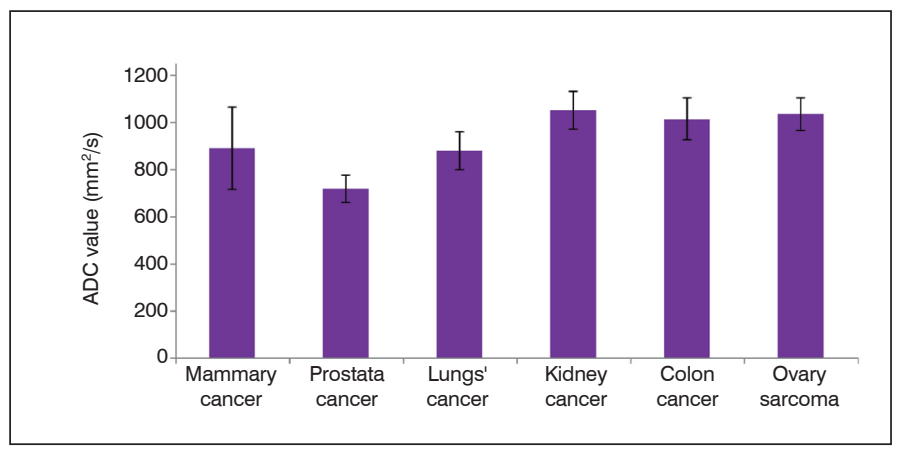

Figure 2. Mean ADC in various types of metastatic spine tumors

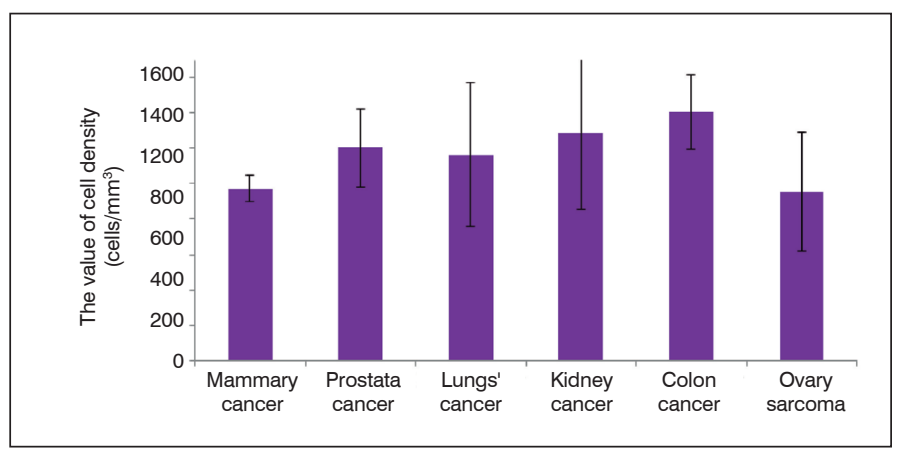

Figure 3. Mean cell density in different types of metastatic spine tumors.

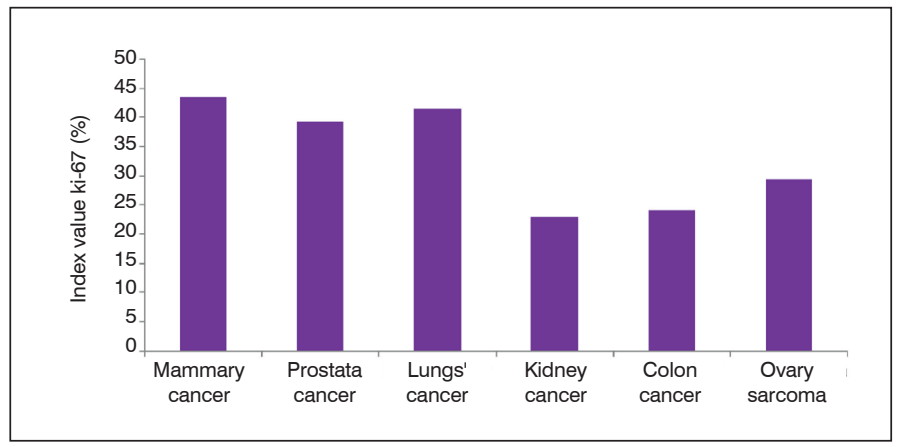

Figure 4. Mean Ki-67 proliferation index in different types of metastatic spine tumors. 


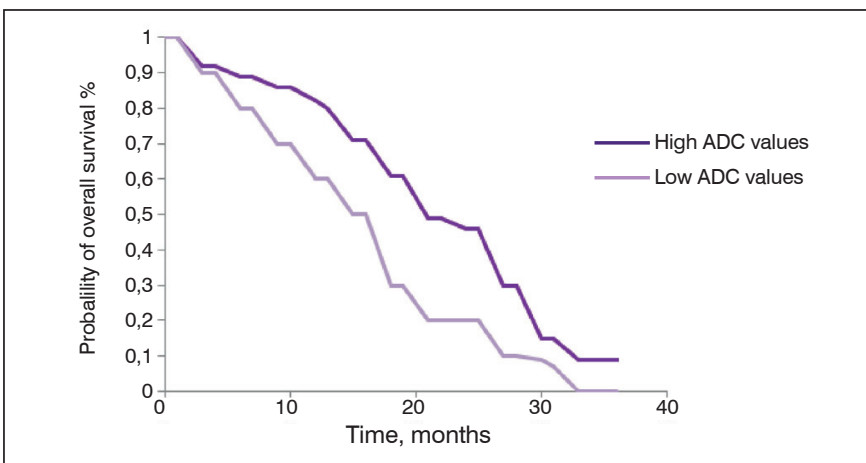

Note: high ADC > 964.8mm2/sec: median 10.2 months. (9.5-12.4); low ADC < 964.8mm2/sec: median 7.3 months $(4.1-10.5), p=0.021$

Figure 5. The Kaplan-Meier curves for low and high ADC values show the overall survival of patients with metastatic spine tumors.

index was also noted in the studies. ${ }^{18,19,20}$ Based on these studies, we came to the conclusion that low ADC values in the areas of neoplastic process are related to peculiarities of pathophysiology and microstructural properties of the tumor tissue. The collagen-rich tumor stroma and argentophilic fibers significantly restrict the diffusion of free water molecules, which is reflected in low ADC values. Other researchers share this opinion. ${ }^{20-23}$ According to our data, there was a significant inverse correlation between ADC values and the Ki-67 proliferation index $(r=-0.756, p=0.017)$ for spine metastases. Most authors in the literature report a correlation between aggressive growth of the tumor and high Ki-67 proliferation index, with a poor prognosis for patient survival time. ${ }^{24}$

There have been several studies focusing on the correlation between ADC values of metastatic tumors and overall patient survival. ${ }^{25-27}$

It was clearly demonstrated in a study by $\mathrm{R}$. Zakaria et al. ${ }^{26}$ that if the ADC value of metastatic brain tumors is greater than $919.4 \mathrm{~mm}^{2} / \mathrm{sec}$, a significant increase in overall survival is noted (9.7 months $(95 \%$ $\mathrm{Cl}$ : 8.5-11.0) versus 6.2 months $(95 \% \mathrm{Cl}: 3.7-8.8), p=0.049)$. C.-C. Lee et al. ${ }^{27}$ in his clinical series of 42 patients with brain metastases, did not observe any significant differences in overall survival of patients with different ACD values following a course of radiosurgery. In our study, there was a statistically significant correlation between ADC values and overall survival in patients with spine metastases that correlates with some literature data. However, the overall survival of patients with ADC value greater than 964.8 $\mathrm{mm}^{2} / \mathrm{s}$ was 10.2 months (95\% Cl: 9.5-12.4), while that of patients with ADC brain metastases less than $964.8 \mathrm{~mm}^{2} / \mathrm{s}$ was 7.3 months (95\% Cl: 4.1-10.5, $p=0.021$ ).

The management of patients with metastatic spinal tumor depends on a number of factors. The most important predictor of patient survival is the ability to walk after treatment. The choice of conduct should be based on an assessment of the stability or instability of the lesion. The Spinal Instability Neoplastic Score (SINS), ${ }^{10}$ which is linked to the characteristics of the metastasis, has been developed for this purpose. Thus, patients with a SINS score of $>7$ require the advice of the surgeon. There have been a number of recent studies on the clinical predictive value of the SINS score. In cases with multiple bone metastases, surgery is always palliative. Pathological fractures of the vertebrae and spinal cord compression by the paravertebral component of the tumor will inevitably cause pain, neurological deficit, impaired function and reduced quality of life, and are indications for early surgical intervention to prevent permanent neurological deficits and disability and maintain function and quality of life. Hibberd and other researchers recommend prophylactic or therapeutic decompressive and stabilization surgery in patients with osteolytic spinal metastases with lesions more than $25 \%$ of the vertebral body and involvement of the vertebral end plates of the vertebral bodies or all three vertebral discs. ${ }^{5}$ In rare cases, surgical decompression of the spinal cord in the context of metastatic tumors is complicated by neurological disorders and neurological complications, which occur mainly during the resection of tumors located in the thoracic spine. ${ }^{9}$ Surgical treatment is indicated for patients with an estimated life expectancy of more than 3 months, and should provide them the optimum quality of life. Life expectancy can be evaluated using the scoring system proposed by Tokuhashi et al. ${ }^{4}$ This scale includes criteria for evaluating the patient's condition, the degree of neurological deficit, the nature of the tumor, the presence of myelopathy and the number of secondary lesions in the spine and other organs. A system of prognostic factors proposed by Bollen performs better than other models. According to data from various studies, the patient's life expectancy is mainly determined by the histology of the primary tumor. The proposed rating system also takes into account the Karnofsky performance status scale and the presence of visceral metastases. As a rule, patients with metastatic lesions of the spinal cord undergo palliative operations to provide decompression at the level of the affected segment. More complex reconstructive surgeries, replacing vertebral bones by bone grafts or their substitutes, are conducted for patients with single metastases without neurological deficits. Generally, these surgical procedures are more radical, and further radiation and chemotherapy are required, depending on the histological characteristics of the primary tumor. According to the recommendations ${ }^{11}$ based on data from a systematic literature review, a patient with neurological deficit from metastatic epidural spinal cord compression (MESCC) leading to loss of ability to walk (without any medical or oncological contraindications) requires urgent surgical decompression. Rapid diagnosis and operative surgery are recommended, to increase the likelihood of neurological recovery.

\section{Limitations of the study}

This research has several limitations that should be identified. The study is retrospective, based on data obtained at a single center with a small number of examined patients that was insufficient to affect the power of statistical analysis. Also, it was difficult to calculate the ADC values defined in our clinical series with results of other studies, due to the use of different MRI systems and programs for calculating this value.

\section{CONCLUSION}

The high rate of spinal metastatic lesions, the emergence of new possibilities of chemotherapy, radiotherapy and surgery, and the improvements in new diagnostic methods demand more effective results of treatment of cancer patients. In the surgical decision making process, the physician should take specific criteria into account, and should consider the estimated quality of life after surgery. MRI is a highly specific diagnostic method for metastatic lesions of the spine that enables a differential diagnosis, and allows the extent of the pathological process to be determined. Also, the ADC values can be a statistically significant prognostic factor for overall survival of patients with spinal metastases.

All authors declare no potential conflict of interest related to this article.

CONTRIBUTION OF THE AUTHORS: Each author made significant individual contributions to this manuscript. VAB (0000-0003-4349-7101) was the main contributor in the drafting of the manuscript. IAS (0000-0001-9039-9147) performed the surgery and patient follow-up and gathered clinical data. AIK (0000-0001-8763-2905) evaluated the data from the statistical analysis. IAS (0000-0001-9039-9147) and VAB (0000-0003-4349-710) performed the literature search and review of the manuscript, and contributed to the intellectual concept of the study. *ORCID (Open Researcher and Contributor ID) 


\section{REFERENCES}

1. Bollen L, van der Linden YM, Pondaag W, Fiocco M, Pattynama BP, Marijnen CA, et al. Prognostic factors associated with survival in patients with symptomatic spinal bone metastases: a retrospective cohort study of 1,043 patients. Neuro Oncol. 2014;16(7):991-8.

2. Kornienko VN, Pronin IN. Diagnostic Neuroradiology. Switzerland: Springer; 2006

3. Egger K, Hohenhaus M, Van Velthoven V, Heil S, Urbach H. Spinal diffusion tensor tractography for differentiation of intramedullary tumor-suspected lesions. Eur J Radiol. 2016:85(12):2275-80.

4. Tokuhashi $Y$, Matsuzaki H, Oda H, Oshima M, Ryu J. A revised scoring system for preoperative evaluation of metastatic spine tumor prognosis. Spine (Phila Pa 1976). 2005:30(19):2186-91.

5. Hibberd CS, Quan GMY. Risk Factors for Pathological Fracture and Metastatic Epidural Spinal Cord Compression in Patients With Spinal Metastases. Orthopedics. 2018;41(1):e38-45.

6. Raaymakers BW, Jürgenliemk-Schulz IM, Bol GH, Glitzner M, Kotte ANTJ, van Asselen $B$, et al. First patients treated with a 1.5 T MRI-Linac: clinical proof of concept of a high-precision, high-field MRI guided radiotherapy treatment. Phys Med Biol. 2017:62(23):L41-50.

7. Winfield JM, Poillucci G, Blackledge MD, Collins DJ, Shah V, Tunariu N, et al. Apparent diffusion coefficient of vertebral haemangiomas allows differentiation from malignant focal deposits in whole-body diffusion-weighted MRI. Eur Radiol. 2018;28(4):1687-91.

8. Hill M, Richards MA, Gregory WM, Smith P, Rubens RD. Spinal cord compression in breast cancer: a review of 70 cases. Br J Cancer. 1993;68(5):969-73.

9. Biega P, Guzik G, Pitera T. Neurological Complications after Surgical Treatment of Metastatic Tumours of the Spine. Ortop Traumatol Rehabil. 2017;19(3):239-47.

10. Fisher CG, DiPaola CP, Ryken TC, Bilsky MH, Shaffrey Cl, Berven SH, et al. A novel classification system for spinal instability in neoplastic disease: an evidence-based approach and expert consensus from the Spine Oncology Study Group. Spine (Phila Pa 1976). 2010:35(22):E1221-9.

11. Laufer I, Zuckerman SL, Bird JE, Bilsky MH, Lazáry Á, Quraishi NA, et al. Predicting neurologic recovery after surgery in patients with deficits secondary to MESCC: systematic review. Spine (Phila Pa 1976). 2016:41(Suppl 20):S224-30.

12. Abercrombie M. Estimation of nuclear population from microtome sections. Anat Rec 1946;94:239-47.

13. Sugahara T, Korogi Y, Kochi M, Ikushima I, Shigematu Y, Hirai T, et al. Usefulness of diffusion-weighted MRI with echo-planar technique in the evaluation of cellularity in gliomas. J Magn Reson Imaging. 1999;9(1):53-60.

14. Nakajo M, Kaijiya Y, Kaneko T, Kaneko Y, Takasaki T, Tani A, et al. FDG PET/CT and diffusionweighted imaging for breast cancer: prognostic value of maximum standardized uptake values and apparent diffusion coefficient values of the primary lesion. Eur J Nucl Med Mol Imaging. 2010:37(11):2011-20.

15. Ohno Y, Koyama H, Yoshikawa T, Matsumoto K, Aoyama N, Onishi Y, et al. Diffusion-weighted MRI versus 18F-FDG PET/CT: performance as predictors of tumor treatment response and patient survival in patients with non-small cell lung cancer receiving chemoradiotherapy. AJR Am J Roentgenol. 2012;198(1):75-82.

16. Duygulu G, Ovali GY, Calli C, Kitis O, Yünten N, Akalin T, et al. Intracerebral metastasis showing restricted diffusion: correlation with histopathologic findings. Eur J Radiol. 2010;74(1):117-20

17. Hayashida Y, Hirai T, Morishita S, Kitajima M, Murakami R, Korogi Y, et al. Diffusion-weighted imaging of metastatic brain tumors: comparison with histologic type and tumor cellularity. AJNR Am J Neuroradiol. 2006:27(7):1419-25.

18. Zheng G, Cheng X, Wang L, Xu Z, Gao X, Yu P, et al. Correlation of MRI apparent diffusion coeffcient with molecular marker Ki-67 in gastric cancer. Zhonghua Wei Chang Wai Ke Za Zhi. 2017;20(7):803-8.

19. Huang Z, Xu X, Meng X, Hou Z, Liu F, Hua Q, et al. Correlations between ADC values and molecular markers of Ki-67 and HIF-10 in hepatocellular carcinoma. Eur J Radiol. 2015:84(12):2464-9.

20. Byvaltsev VA, Stupak VV, Stepanov IA, Kichigin AI. Dpplication of the apparent diffusion coefficient in preoperative assessment of the proliferative potential of spinal tumors. Spine Surgery. 2017;14(3):93-9.

21. Langley RR, Fidler IJ. The seed and soil hypothesis revisited-the role of tumor-stroma interactions in metastasis to different organs. Int J Cancer. 2011;128(11):2527-35.

22. Moorman AM, Vink R, Heijmans HJ, van der Palen J, Kouwenhoven EA. The prognostic value of tumour-stroma ratio in triple-negative breast cancer. Eur J Surg Oncol. 2012;38(4):307-13.

23. Byvaltsev VA, Stepanov IA, Kichigin AI, Antipina SL. Diffusion-weighted MR in the differential diagnosis of brain meningiomas. Siberian Journal of Oncology. 2017;16(3):19-26.

24. Tian Y, Ma Z, Chen Z, Li M, Wu Z, Hong M, et al. Clinicopathological and Prognostic Value of Ki-67 Expression in Bladder Cancer: A Systematic Review and Meta-Analysis. PLoS One. 2016;11(7):e0158891.

25. Byvaltsev VA, Stepanov IA, Kichigin AI, Kanigin VV, Stupak VV. The role of diffusionweighted $\mathrm{MRI}$ in differential diagnosis and prediction of survival in patients with brain metastases. Annals of the Russian academy of medical sciences. 2017;72(6):442-9.

26. Zakaria R, Das K, Radon M, Bhojak M, Rudland PR, Sluming V, et al. Diffusionweighted MRI characteristics of the cerebral metastasis to brain boundary predicts patient outcomes. BMC Med Imaging. 2014;14:26

27. Lee CC, Wintermark M, Xu Z, Yen CP, Schlesinger D, Sheehan JP. Application of diffusion-weighted magnetic resonance imaging to predict the intracranial metastatic tumor response to gamma knife radiosurgery. J Neurooncol. 2014;118(2):351-61. 